Acta regionalia et environmentalica 1

Nitra, Slovaca Universitas Agriculturae Nitriae, 2014, p. 18-23

\title{
METHODS OF PUBLIC COMMUNICATION AND RELATED PERCEPTION OF TRANSPARENCY FROM THE SLOVAK MUNICIPALITIES' POINT OF VIEW
}

\author{
Milan FIL'A*, Loreta SCHWARCZOVÁ \\ Slovak University of Agriculture in Nitra, Slovak Republic
}

\begin{abstract}
The significance of the communication of the public sector at the level of the local government has recently increased essentially. Today's information society brings an advanced and fast communication which must be adapted by the representatives of the municipalities. This fact is related not only to ensuring greater objective transparency but also in ensuring the possibility for citizens to actively participate in public affairs in the environment where they live, as well as to evaluate the events and actions of local governments. The paper evaluates the current utilization of direct and indirect methods of communication and also points out the statistically significant preference evaluation of selected changes of the Act on free access to information by the representatives of municipalities in terms of increased use of information and transparency towards the citizens (towards the general public).
\end{abstract}

Keywords: communication, citizens, municipalities and regions

The communication is an integral part of the daily lives of people who use the elements of this process for the transfer of necessary information, knowledge, experience, and thus ensure the functioning of the whole society. At present, it is more and more stressed that we live in the so-called "information period" and create the knowledge based society built on the pillars of information and knowledge economy. The information period also brought the much greater openness and access to information of different nature. This actual trend has to be definitely followed by the state and public administration as well as by regional and local municipalities since the identification and consequent accessibility of information is perceived by the citizens as a tool of public control and at the same time a way of permanent enhancement of the level of public services provided.

Žiaková (2010) indicates the following principles of public communication: openness and transparency, confidentiality, impartiality, clarity and timeliness.

For the transparent public communication, we agree with the opinion of Heger (2012) based on which for the systematic public communication, it is essential that the municipality - similarly as the commercial organization should create the communication strategy which should represent the consensus between the political and professional municipality management.

According to Meffert (1999), municipalities use the communication process in order to mediate the "corporate identity $(\mathrm{Cl})$ " to their key stakeholders. For this purpose, municipalities use the coordinated set of communication tools. The communication used by municipalities is tightly linked to promotion (marketing) activities, public relations activities (PR) and other tools of marketing communication.

As demonstrated by Bernátová and Vaňová (2000), the significant precondition of correctly functioning democracy is just the communication between its components - municipality and citizens. In relation to this, the communication process should not be a one-way but in any case it should represent a bi-directional functioning process. Thus, the municipality should not just announce information to the citizens but also play an active role of the recipient. In the frame of such a communication model, a citizen should represent the active component of the communication process. Almost identical opinion is presented by Foret (2011) according to who the communication strategy should be of maximum effectiveness and should contribute to the cooperation, promotion and expansion of municipalities and on the other hand, the communication strategy should provide citizens with relevant information. The significance of a municipality in the context of democracy is also highlighted by Koudelka (2007) when indicating that the municipality is an integral part of democracy and expresses rights and competencies of municipality authorities in favour of the interests of citizens in forms of regulating and managing public issues.

Approximately $55 \%$ of Slovak inhabitants live currently in 136 Slovak municipalities and exactly this category of communication process citizen - municipality is the subject of our research.

\section{Material and methods}

The paper focuses on the evaluation of the current utilization of direct and indirect methods of communication and also points out the statistically significant preference evaluation of selected changes of the Act on free access to information by the representatives of municipalities in terms of increased use of information and transparency towards the public. When processing the paper, the available theoretical knowledge of domestic and foreign references served as secondary source of information.

For the purpose of obtaining relevant primary data and sources, the survey on the basis of the questionnaires has 
been carried out at the level of 136 Slovak municipalities. When researching the complex issues, the methods of the questionnaire survey, analysis, synthesis and comparison of achieved results were carried out. The sample of 136 questioned Slovak municipalities created the basic research file. The survey was focused on the field of the level of citizens 'satisfaction and their opinions in relation to their awareness by the municipalities as well as in relation to the forms of identification and publication of information. The created set of questions was responded by staff members of municipalities responsible for public communication (Heads of Communication Departments or Public Relations Departments). The size of the file of municipalities which completed the questionnaire and thus provided data and information was 124. The file of 124 municipalities was processed and was subject to research. From the overall amount of 136 Slovak municipalities $91.18 \%$ were subject to the research. To verify the representativeness of the file the test statistic Pearson $\mathrm{Chi}$ - square test of fit was used:

$$
\chi^{2}=\sum_{i=1}^{r} \frac{\left(n_{i}-e_{i}\right)^{2}}{e_{i}}
$$

This statistics has asymptotically $\chi^{2}$ distribution with $\mathrm{r}-1$ degrees of freedom. It is based on frequency tables and statistical test of the null hypothesis, which argues that the frequency in each category is equal to the expected (theoretical) frequency (Rimarčík, 2007). Based on the realized calculation of test characteristics $(\mathrm{TCH})$ and its comparison with the table (critical) value $(\mathrm{KH})$, we can confirm the null hypothesis and thus the surveyed sample of municipalities is representative.

Table 1 Chi-Square Goodness of Fit Test

\begin{tabular}{|l||c|}
\hline Alfa & 0.05 \\
\hline TCH & 0.3604351 \\
\hline KH & 14.06714045 \\
\hline \multicolumn{2}{|c|}{ TCH $<$ KH } \\
\hline
\end{tabular}

Examining the responses received from the questionnaires we have focused on the identification and verification of the existing preferences within the responses related to the perception and evaluation of the transparency in relation to the Amendment of the Act on free access to Information.

For the verification, the Kolmogorov-Smirnov test was used as a nonparametric test for the equality of continuous, one-dimensional probability distributions that can be used to compare a sample with a reference probability distribution. The Kolmogorov-Smirnov statistics quantifies a distance between the empirical distribution function of the sample and the cumulative distribution function of the reference distribution. The testing is focused on null hypothesis $H_{0}: F(x)=G(x)$ for all against to alternative hypothesis $H_{1}: F(x) \neq G(x)$ at least for one $x$, while $F$ and $G$ are distribution functions of two independent samples. Testing characteristics $D$ is calculated according to the following relation:

$$
D=\max \left|E_{i}-T_{i}\right|
$$

It is compared with the table value $H$ whose calculation is dependent on the chosen level of significance and is determined by the following functional relation:

$$
H=\sqrt{-\frac{\frac{\ln \alpha}{2}}{2 n}}
$$

$\frac{1.36}{\sqrt{n}}$ for $\alpha=0.05$

Based on the identified results of the questionnaire, the conclusions are formulated related to the communication process carried out between the citizens and municipalities in the Slovak Republic.

\section{Results and discussion}

Open, regular and two-way communication of municipalities with their citizens is a significant indicator of democracy and sophistication of today's modern society based on information. We share the opinion of cited authors and professionals from the field in this paper since the nature and importance of communication at the level of municipalities and citizens is significantly represented. This way of communication provides the citizens with the access to information on one hand, and provides them with the opportunity to participate directly or indirectly in the local governance on the other hand.

\section{Direct forms of communication}

Within the realized research and evaluation of the used direct forms of communication of Slovak municipalities with citizens, the quite often demonstrated opinions and answers did not conform to modern trends in direct communication between government - public administration - local government and citizens. As demonstrated by the Figure 1,

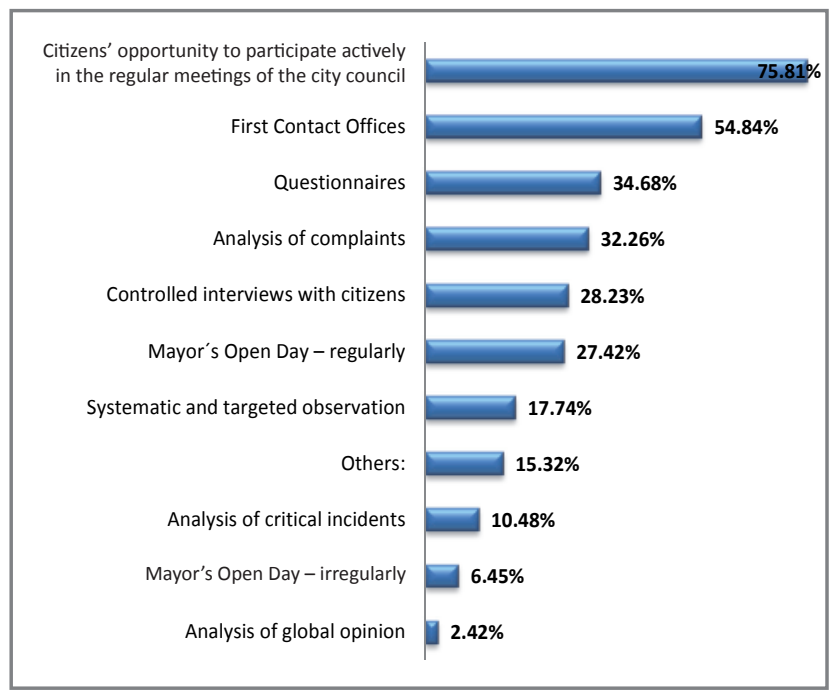

Figure 1 The forms of direct communication used by Slovak municipalities 


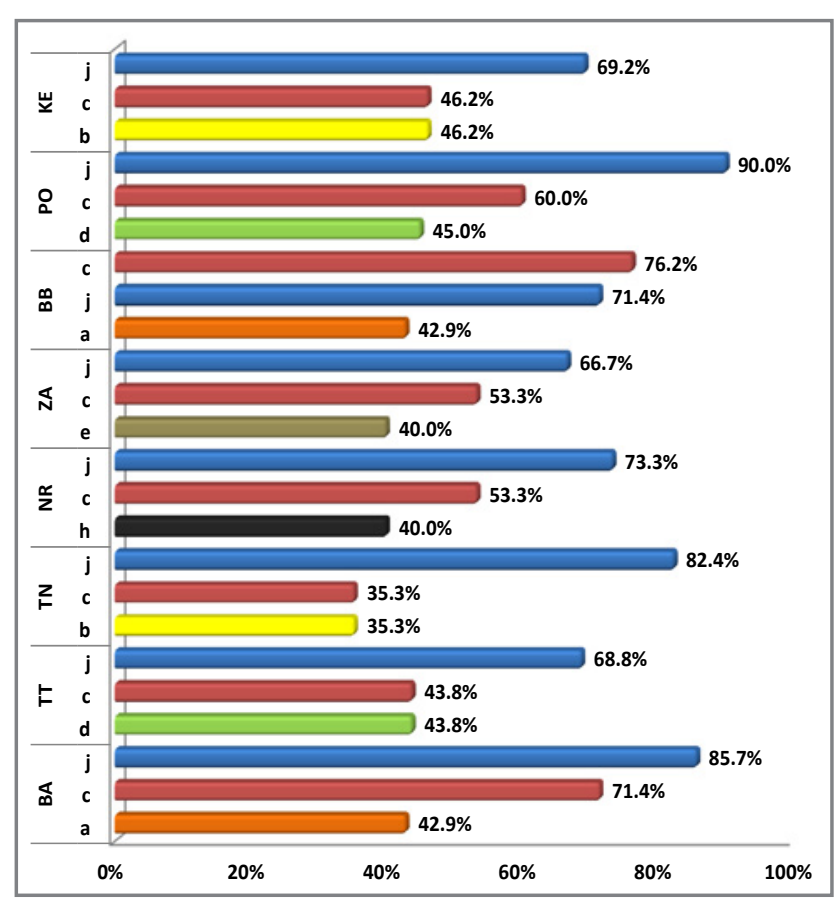

Figure 2 The most frequent forms of direct communication used by municipalities in Slovak regions

the most frequently used form of direct communication of municipalities with citizens is the opportunity of citizens to participate actively in the regular meetings of the city council (75.81\%) which paradoxically evokes the way of communication at the level of small rural communities.

At the present, so-called First Contact Offices come to the foreground while more than the half of Slovak municipalities (54.84\%) already operates such offices. As a part of the ongoing reforms in the public sector it can be expected that this number will continuously increase. Approximately $1 / 3$ of municipalities are currently using the questionnaire survey in order to assess the level of satisfaction of their citizens. Almost the identical share of municipalities organize the "Mayor's Open Day" which enables regular or irregular personal visit with the mayor, and thus the citizens are provided with information on the work of the local government. This tool serves also for the purpose of solving existing problems and proposals.

The municipalities are also realizing the analysis of complaints (34.68\% of municipalities). Other examples of tools used within the direct communication process were competitions and surveys via the website. The use of these tools of direct communication is rather marginal in Slovak cities.

From the regional perspective, in all regions except of the Banská Bystrica self-governing region the most frequently used form of direct communication with citizens are active participation of citizens at the city council meeting with the utilization rates from 66.7 to $90 \%$ (j). In the Banská Bystrica region, there is a slight dominancy of the use of the first contact offices where citizens can address their needs, issues, complaints or receive the necessary information. First contact offices are also the second most utilized form of direct communication with citizens in all remaining regions of Slovakia with a utilization rate of 35.3 to $76.2 \%$ (c) of municipalities. At the same time, there is a significant assumption that the reform of public administration will also push on the local government authorities to set up such offices and to facilitate better communication and services for their citizens. The third most utilized form of direct communication in individual regions differs considerably. While in the Košice and Trenčín regions there are guided interviews with citizens (b) (35.3 to $46.2 \%$ of municipalities), in the Prešov and Trnava regions there is analysis of complaints (d) prevails ( 43.8 to $45 \%$ of municipalities). In the Banská Bystrica and Bratislava regions the questionnaires (a) predominate (35.3 to $46.2 \%$ of municipalities), while in the Nitra region, the regularly organized Mayor's open days (h) predominantly prevail (40\% of municipalities). As much as $40 \%$ of municipalities of the Žilina region use systematic targeted monitoring.

\section{Indirect forms of communication}

From the indirect communication point of view, almost each Slovak municipality manages an interactive website (95.16\%). This fact results from the legislation and it is evidently the most commonly used form of indirect communication with the citizens. This communication method provides mutually - for municipality representatives and for citizens - the high level of comfort and speed of publishing and access to information. In spite of the extended use of the Internet, the significant share of indirect communication is represented by the use of a physical official notice board in the municipality (86.29\% of municipalities) and approximately the comparable share is represented by local print magazine published by a municipality either periodically or non-periodically. In majority of cases, the use of local radio presents still an important source of information, especially in smaller towns. Secondly, the use of local television is extended, which is currently available and used by more than a half of Slovak towns (55.65\%)

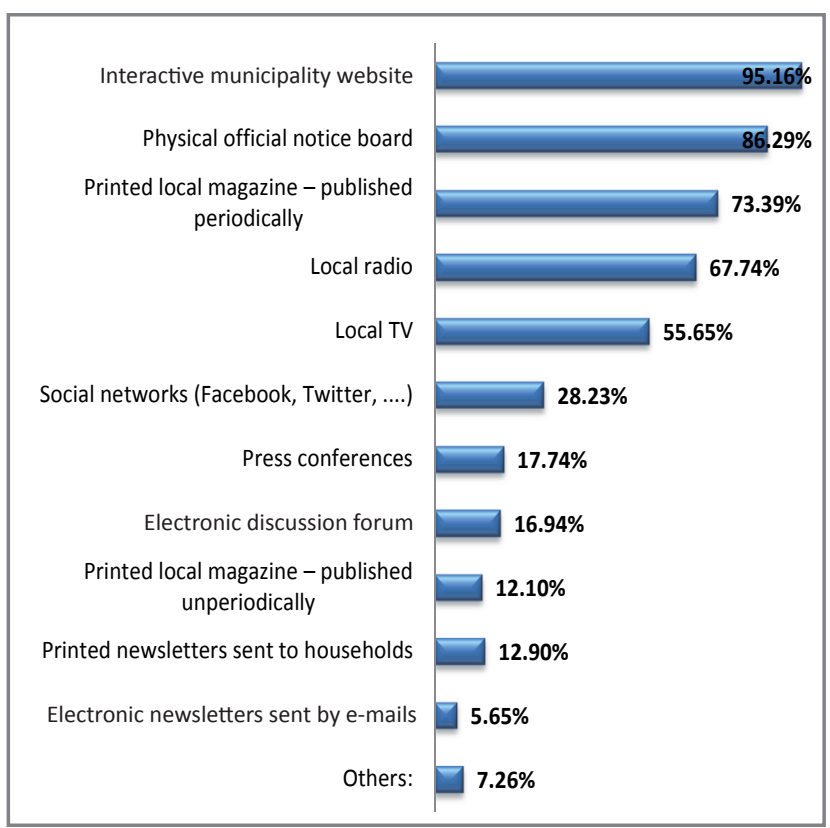

Figure 3 Indirect forms of communication used by Slovak municipalities with citizens 


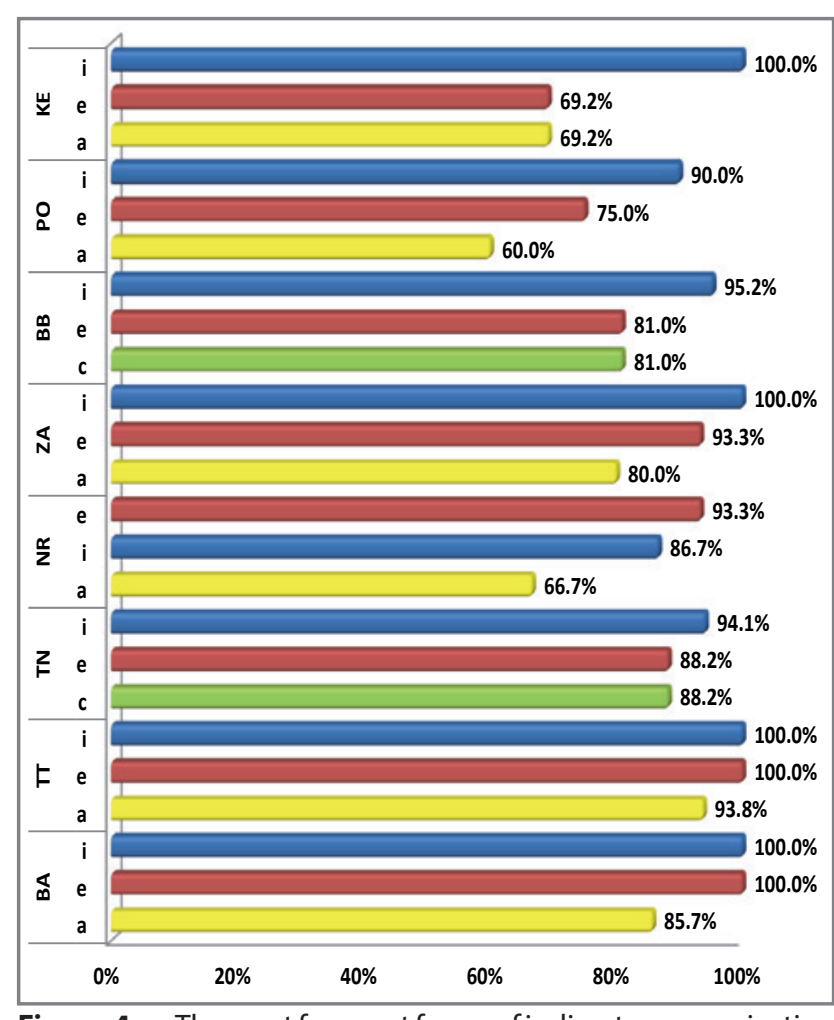

Figure 4 The most frequent forms of indirect communication used by municipalities in Slovak regions

During the past several years and especially in larger cities, the use of social networks has extended. This is definitely the tool which represents incredibly fast and efficient method of communication with citizens.

This phenomenon has been understood by more than $1 / 4$ of municipalities which address their citizens by this tool. Positive examples are represented by regional cities such as Nitra or the capital Bratislava, but also smaller district towns in the Slovak Republic such as Levice, Čadca, and Spišská Nová Ves. Also the use of electronic discussion forums start to be discovered (i.e. Levoča, Nitra) as well as the sending of electronic circulars. These communication tools are contemporary used just marginally and in cases of small amount of Slovak municipalities.

As we can see in the Figure 4 above, from a regional perspective, there are no significant statistical differences in the use of indirect forms of communication. In all regions except of the Nitra region, the most frequently used communication tool is a website (i) -86.7 to $100 \%$ of municipalities.

Municipalities in the Nitra region use most frequently the indirect communication with citizens via official notice board (e) in physical form (93.3\% of cases). In all other regions, the official notice board stands for the $2^{\text {nd }}$ position as for the most common use of indirect communication with the percentage utilization of 69.2 to $100 \%$ of municipalities. In the Bratislava and Trnava regions, the official notice board has an identically important function and usability as a Website. Thus, the municipalities obviously use all indirect communication via modern electronic and classical physical way by which the broad coverage of the wide public is arranged. The third most frequently used method of indirect communication in six regions is a printed local magazine (a) with use of 60 to $93.8 \%$ of municipalities. In the Trenčín and Banská Bystrica regions, there is one method of indirect communication slightly preferred to a printed local magazine - a local radio (c) used by $81-88.2 \%$ of municipalities of these regions.

\section{Transparency and mandatory publishing of information in Slovak cities}

The mandatory publishing and accessing of information is legally regulated by Act no. 211/2000 Coll. on free access to information as amended by subsequent legislation (hereinafter only "Act"). The Act obliges the obliged person to access information while defines them as state authorities, municipalities, as well as legal and natural persons to whom the law confers competencies on the right and obligations of natural and legal persons in public administration and in particular in the extent of their decision-making activities. According to the Act, the obliged persons are also cities and villages, or their mayors, city or municipal councils, local, urban or even municipal authorities. The obligated persons are also represented by legal entities established by law and legal entities established by national authorities, regional governments or by the municipality according to a special law - thus, also legal persons established by the municipality for specific purposes. As results from the previous assessment of communication of municipalities with citizens, the most frequently used method of communication as well as the method publishing the mandatory data and documents is publishing via websites.

The existence of an official website is required by law. In relation to the Act on free access to information we focused our research also on the much discussed amendment no. $546 / 2010$ Coll. by which the publishing of orders, contracts and invoices of obliged persons on the internet was implemented.

As Figure 5 shows, the overall perception of municipalities is rather positive with the passage of time in $54 \%$ of cases. Approximately $1 / 4$ of municipalities presented their neutral position, and only about $13 \%$ of the municipalities perceive this amendment negatively. The negative attitude was in

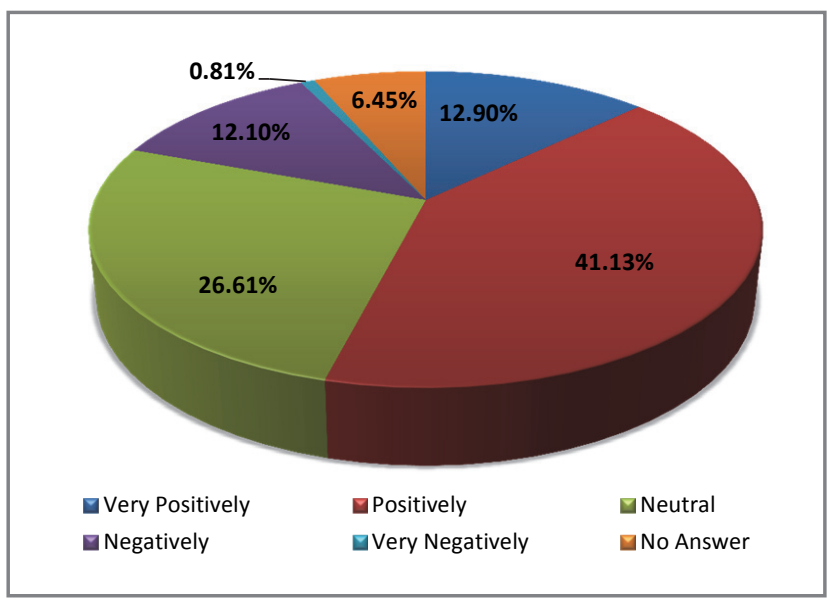

Figure 5 The overall perception of the amendment No. 546/2010 Coll. of the Act no. 211/2000 Coll. on free access to informations 
majority of cases explained by the increase of bureaucracy and financial burden (administrative and electronic processing of documents and their subsequent publishing on the Internet), especially in smaller towns which do not have sufficient technical, human and financial capacity.

Significant positive preferences in relation to the overall perception of the amendment no. 546/2010 Coll. are proved by results of the Kolmogorov-Smirnov test presented in Table 2. By comparing the test characteristics and tabulated values we found out that the null hypothesis can be rejected and the alternative hypothesis $\mathrm{H} 1$ can be accepted. Thereby, we confirmed our assumption that there are statistically significant differences in preferences of Slovak municipalities.

Table 2 Kolmogorov-Smirnov test (overall perception of the amendment no. 546/2010 Coll.)

\begin{tabular}{|l||c|c|}
\hline N & 124 & \\
\hline Alfa & 0.05 & \\
\hline \multicolumn{3}{|c|}{ Values } \\
\hline D test & 0.30645 & max. value of abs (Fi-Gi) \\
\hline D tab & 0.12213 & \\
\hline \multicolumn{3}{|c|}{ D test $>$ D tab } \\
\hline
\end{tabular}

From the amendment (no. 546/2010 Coll.) municipalities perception point of view more than $83 \%$ of a municipality claims that the amendment has a positive impact as for the increasing measure of awareness and transparency. In contrary, just $13 \%$ of municipalities prove the opposite, namely that the amendment did not bring greater awareness and transparency. From additional interviews or comments revealed the fact that municipalities consider the amendment as the source of another unnecessary administration, which is not an effective solution of the purpose intended by the Act.

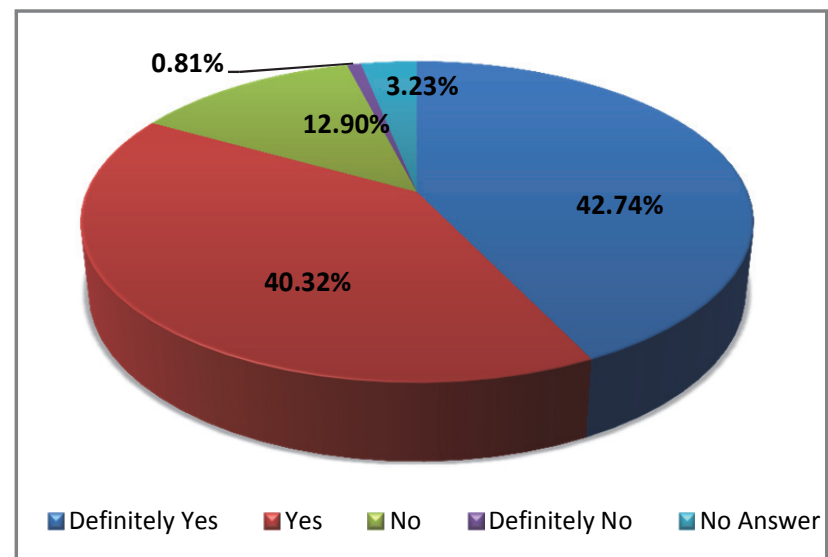

Figure 6 Perception of the amendment no. 546/2010 Coll. to the Act no. 211/2000 Coll. from the Slovak municipalities' side from the increasing measure of awareness and transparency point of view

Significant positive preferences in relation to the perception of the amendment no. 546/2010 Coll. from the increasing measure of awareness and transparency point of view are proved by the results of Kolmogorov-Smirnov test in Table 3. By comparing the test characteristics and tabulated values, we found out that we can reject the null hypothesis $\mathrm{HO}$ and accept the alternative hypothesis $\mathrm{H} 1$, by which we confirmed our assumption that in the preferences of cities in the Slovak Republic there are statistically significant differences.

Table 3 Kolmogorov-Smirnov test (overall perception of the amendment no. 546/2010 Coll. - in terms of increasing the level of information and transparency)

\begin{tabular}{|c|c|c|}
\hline $\mathbf{n}$ & 124 & \\
\hline alfa & 0.05 & \\
\hline \multicolumn{3}{|c|}{ Values } \\
\hline D test & 0.430645 & max.value of abs (Fi-Gi) \\
\hline D tab & 0.12213 & \\
\hline \multicolumn{3}{|c|}{$D$ test $>D$ tab } \\
\hline
\end{tabular}

Paradoxically, taking into consideration the initially presented public criticism from the municipalities in relation to the amendment, we expected that preferences in both cases would statistically be significant, but in favour of negative preferences. The survey, however, showed that with the passage of time, the Slovak municipalities "became familiar" with this amendment and they perceive it as the tool facilitating more transparent view for their citizens. Some municipalities implemented this procedure prior to the change, and some go well beyond its framework, while trying to promote open government projects (i.e. Martin via the project "Transparent town"), or the Žilina self-governing region via the project "open region" realized by the support of Transparency International, Slovakia with the main aim to ensure the transparency and awareness towards their own citizens.

\section{Conclusion}

On the basis of the findings we can conclude that Slovak municipalities currently still predominantly use traditional forms of direct and indirect methods of communication, while also advanced communication tools such as social networks, electronic forums or first contact offices for citizens are progressively being introduced. In terms of provision and access to information, the website and physical Notice board are of key importance. At present, representatives of municipalities statistically significantly perceive the amendment to the Act on Free Access to Information positively - it introduced mandatory publishing of orders, contracts and invoices for websites or central registry contracts. Objections to the Act are directed to the field of Act abuse by several groups of citizens who seek data difficulty be created and provided due to time consuming aspect and due to the lack of technical and personal capacities. For this reason, the current legislative initiative of the government is more than actual when there is an effort to adjust the Act on the way in order to serve its purpose and at the same time not to allow the Act to be a tool for abusing by selected groups of citizens. Legislative 
regulation developed in cooperation with local authorities as well as the support of the introduction of new modern methods of interactive communication with citizens may contribute to further enhancement of positive image of the state and public administration as well as of local and regional government. Considerable role is played by wider support of projects which enhance the level of transparency such as "Transparent town" and Open Region" carried out by Martin, Šal'a or the Žilina self-governing region. These are also essential ways of communication which create positive relations, open monitoring opportunities and cooperation with citizens.

\section{References}

BERNÁTOVÁ, M. - VAŇOVÁ, A. 2000. Marketing pre samosprávy I. Marketing území. Banská Bystrica : IROMAR and EF UMB, 2000. p. 180. ISBN 80-8055-337-8.

FORET, M. 2011. Marketingová komunikace 3. vyd. Brno: Computer press, 2011. p. 379-425. ISBN 978-80-251-3432-0

HEGER, V. 2012. Komunikace ve veřejné správe 1. vydanie. Praha: Grada Publishing a.s. 256 p. ISBN 978-80-247-3779-9

KOUDELKA, Z. 2007. Samospráva. Praha : LINDE PRAHA a.s., 2007. 397 p. ISBN 978-80-7201-665-5
MEFFERT, H. 1999. Marketing. Wiesbaden, 1999. p. 160. ISBN 975-51-236-9076-7

RIMARČÍK, M. 2007. Štatistika pre prax. 1. vydanie. Košice : Marián Rimarčík, 2007. 200 p. ISBN 80-969-8131-1.

ŽIAKOVÁ, M. 2010. Stratégia informovania verejnosti. [online]. 2010, [cit.2014-02-12]. available on the Internet: <http://www. ujd.gov.sk/files/info/Strategia\%20informovania.pdf>

ZÁKON SNR č.369/1990 Zb. o obecnom zriadení v znení neskorších predpisov

ZÁKON č. 211/2000 Z. z. o slobode informácií, In Zákon č. 211/2000 Z. z. o slobodnom prístupe k informáciám a o zmene a doplnení niektorých zákonov (Zákon o slobode informácií)

http://www.martin.sk/transparentne-mesto/d-5999/p1=1048 http://www.sala.sk/cms.article/default/569/otvorene-mesto http://rebeca.sk/?p=3448

http://www.transparency.sk/analyza-hodnotenie/\#hodnotenie \%20samospr\%C3\%A1v

\section{Contact address:}

Milan Fila, Slovak University of Agriculture in Nitra, Faculty of European Studies and Regional Development, Department of European Policies, Tr. Andrea Hlinku 2, 94976 Nitra, Slovak Republic, e-mail: milan.fila@uniag.sk 